\title{
MANUSIA INDONESIA DAN KETERPUTUSAN BUDAYA
}

\author{
Muhammad Anas \\ Fakultas Filsafat Universitas Gadjah Mada Yogyakarta. Jalan Bulaksumur Jogjakarta.Telp. 0274) 549431 \\ hompage: ppb.ugm.ac.id
}

Abstract

Culture becomes the core and the starting point as well in building a great civilization. It includes various thinking system, cultural characteristics, social wishes, and cultural products. Ibn Khalduns concept of culture includes many more elements. Umran (culture) as human creation has a historical dimension. According to Khaldun, culture is not only a heritage from the previous culture, but also umran in becoming. Then, the principle of infisal (discontinue) becomes typical characteristics of society because the principle of separation or discontinuity views that all elements in universe are unrelated to each other. The principle of discontinuity is based on the influence of geographical condition. Besides, some sociological and cultural characteristics also influence rural and urban social lives. For Khaldun, culture is not only the heritage of the previous culture, but also umran in becoming. That is a finding of the concept of culture in designing Islamic culture in the future by considering historical aspects and factors supporting social change in Islam. This concept can be used as a reference in discussing the characteristics of Moslem society in the future and a progressive dimension of change in Islam.

Key words: discontinuity, culture, umran 


\section{Pendahuluan}

Membangun manusia di masa depan memerlukan kesinambungan dengan kehidupan kultural atau kebudayaan masa lalu. Kesadaran akan kontiunitas sejarah dan budaya memperkuat kesadaran diri, sehingga terbentuk identitas diri manusia, identitas yang berbeda dengan lainnya. Pemupukan identitas diri tidak dapat dijalankan tanpa menghidupkan kesadaran kultural. Namun, kenyataannya telah terjadi pemutusan atau keterputusan penerusan budaya yang diwariskan oleh nenek moyang ne-geri ini, entah disengaja atau bahkan tidak disadari. Akibatnya, negeri ini tak mampu menumbuhkan cultural forces yang diperlukan untuk membentengi diri dari berbagai terpaan modernitas yang datang dari Barat.

Pemutusan mata rantai kebudayaan, sikap hidup, pandangan dunia (world view), serta nilai-nilai ketimuran ini awalnya jika dirunut lebih jauh dan mendalam disebabkan oleh feodalisme kolonial Belanda, salah satu contoh konkritnya berupa sistem tanam paksa. Dalam perspektif sejarah silam sebelum Belanda datang, sistem pemerintahan desa dipilih rakyat dengan bebas, ada tanah milik desa dan ada tanah milik individu. Belanda tidak mau tahu dengan sistem ini, yang terpikirkan dalam benak mereka adalah kebutuhan tanah-tanah untuk produksi harganya tinggi di Eropa pada masa itu. Mereka masuk ke pedalaman menjadikan lurah sebagai agennya dan memilih tanah yang baik untuk ditanami (Lubis, 1981: 45-57).

Lurah atau kepala desa yang dahulunya menjadi simbol kegotongroyongan lalu menjadi tuan yang ikut menindas rakyat. Kolonial Hindia Belanda memporak-porandakan sistem dan tata cara masyarakat lokal, dan hingga kini kekacauan sistem ini tetap permanen sampai sekarang. Dari sedikit gambaran di atas dapat diketahui bagaimana proses kolonialisasi itu berjalan, dibentuk, dan melalui berbagai sarana seperti budaya, ekonomi, politik lokal, dan seterusnya. Praktek penanaman pola-pola imperialis tersebut berjalan dan hingga kini masih berperan aktif menggerakkan nalar sebagian besar manusia Indonesia. 
Proses menjadi manusia Indonesia harus dengan rendah hati diterima dalam kesadaran kita sebagai proses lanjutan Hindia Belanda, yang oleh para pendiri bangsa ini secara politis diproklamirkan 18 Agustus 1945 sebagai Republik Indonesia. Meskipun begitu, dengan nada optimis, kebudayaan Indonesia terus berproses menanggapi panggilan-panggilan sejarahnya secara dialektis dari sosok budaya feodalistik, aristokratik menuju ke sosok budaya Indonesia yang maju, beradab, demokratis, terbuka, dan saling menghormati keragaman. Inilah jalan transformasi budaya (Sutrisno, 2004: 134).

Dalam konteks ini, keanekaragaman budaya dan kebhinekaan mendapatkan ruang yang sama untuk tumbuh dengan ikhlas, saling menghormati masing-masing perbedaan dengan keberlainannya (otherness), di mana kita tulus hidup bersama dengan sesama saudara-saudari yang berbeda budaya dan suku tanpa memaksakan cita-cita pretensi hidup baik. Demikian seharusnya sikap yang paling mendasar untuk menjadi manusia yang mengakui keanekaragaman (Sutrisno, 2004: 134).

\section{Refleksi Kebudayaan: Ke Arah Umran in Becaming}

Sebagai subjek kebudayaan, manusia lalu diberikan definisinya, baik dari sifat maupun kodratnya. Beberapa filsuf kebudayaan seperti Notonegoro, misalnya, yang melihat manusia bersifat monopluralis, Von Uexkull dengan gagasan Umwelt, atau pun Max Schaeller yang memahami manusia mempunyai kemampuan imajinasi, atau juga Ortega Y Gasset yang memahami manusia bersifat historis. Semua ini merupakan bentuk refleksi filosofis yang mendalam mengenai sifat, kodrat dan karakteristik manusia. Secara garis besar dapat disimpulkan bahwa ciri utama manusia bukanlah kodrat fisik ataupun kodrat metafisik, melainkan karyanya. Aktivitas-aktivitas manusiawilah yang menentukan dan membatasi dunia kemanusiaan. Bahasa, mitos dan religi, kesenian, sejarah, teknik adalah sektor-sektor penting dalam dunia tersebut. Refleksi filosofis harus mampu menggali struktur dasar masing-masing dari komponen-komponen tersebut. Secara serentak, refleksi filosofis juga memberi kita pemahaman atas seluruh aktivitas berbagai komponen tersebut sebagai satu kesatuan yang terkait 
dalam jejaring satu dengan yang lain. Bahasa, mitos, religi, kesenian bukanlah hasil karya yang tidak saling terkait, akan tetapi justru terintegratif dalam satu ikatan, namun ikatannya bukan ikatan substansial yang dipahami dan digambarkan oleh pemikiran skolastik, melainkan berupa ikatan fungsional sekaligus struktural.

Kebudayaan adalah suatu keseluruhan komplek yang memasukkan semua bentuk ilmu pengetahuan, kepercayaan, seni, hukum-hukum, adatistiadat, dan beberapa kemampuan lain yang diperoleh oleh orang sebagai anggota masyarakat. Faktor internal, sebagaimana pandangan Ibnu Khaldun atau dalam istilah Frans Boas disebut deterministik geografik (keadaan sekeliling menentukan), seperti kondisi geografis dan iklim sangat membentuk daya tanggap manusia terhadap gejala-gejala yang ada di sekitarnya, sehingga melahirkan perbedaan daya tanggap dan ekspresi kemanusiaan sesuai dengan kondisi geografis dan iklim itu sendiri. Daya tanggap manusia yang dibentuk oleh keadaan alam itu lama kelamaan membentuk apa yang ia sebut sebagai umran atau kebudayaan (Sastrapratedja, 1977: 99). Berikut ini beberapa hal yang membentuk kebudayaan:

1. Ilmu dan teknologi yang merupakan hasil pemikiran yang membedakannya dari hewan-hewan lain, karena itu telah menjadikannya lebih mulia dari pada segala mahkluk.

2. Kebutuhan akan seseorang pemimpin yang mengatur dan seorang pengusaha yang berwibawa karena hanya manusialah di antara segala makhluk yang tidak mungkin ada tanpa seseorang yang bertindak seperti itu. Memang ada yang berpendapat bahwa hal ini terdapat juga pada lebah dan belalang, namun dikalangan binatang, hal itu terdapat berdasarkan pemikiran dan renungan.

3. Bermasyarakat (umran) dimaksudkan sebagai sama-sama tinggal dan menjadi penghuni sebuah kota atau kampung untuk hidup bersama dan saling memenuhi kebutuhan, karena dalam watak manusia itu telah terdapat kebutuhan untuk bekerjasama untuk kehidupan dengan demikian, hidup bersama masyarakat merupakan suatu hak yang esensial bagi manusia. 
Jika dihubungkan dengan konsep Ibnu Khaldun maka yang menarik adalah kemampuannya yang luar biasa untuk membangun bagan umran dalam karangan yang cukup luas dan mengandung berbagai aspek kehidupan manusia (Jarvie, 1983: 54). Umran mengandung berbagai elemen. Antara lain (Sastrapratedja, 1977: 21-22):

a. Kondisi psikologis; perbedaan karakter dan temperamen orang-orang yang tinggal dalam masyarakat yang berbeda.

b. Teknologi; seluruh praktek know-how yang menghasilkan barang dan jasa kesejahteraan manusia.

c. Ekonomi; seluruh kegiatan dan berorganisasi manusia yang berhubungan dengan produksi, distribusi dan konsumsi barang-barang dan jasa.

d. Organisasi politik kepemimpinan politik dan aparat pemerintahannya dan pengendalian hubungan-hubungan manusia.

e. Organisasi sosial; struktur masyarakat.

f. Pendidikan; seluruh kegiatan pemindahan ilmu pengetahuan dan cara bertingkah laku.

g. Aspek kelembagaan agama dan sistem kepercayaan dan tingkah laku agama.

h. Budaya simbol, sistem simbol dan teknik menggunakannya, pengantaran dan pemindahan pengetahuan, khususnya melalui bahasa dan kesenian.

Gagasan kebudayaan Ibnu Khaldun tidaklah berhenti sampai di sana. 'Umran (kebudayaan), menurutnya, sebagai suatu kreasi manusia yang mempunyai sebuah "dimensi historis" (Ali, 1985: 333). Oleh karena itu, bagi Ibnu Khaldun, kebudayaan tidak hanya suatu warisan dari kebudayaan terdahulu, melainkan juga umran in becoming (kebudayaan di masa depan). Kebudayaan yang bergerak maju dan progress tanpa memutus turas klasik. Akan tetapi justru turas klasik ini menjadi semacam kearifan tersendiri yang harus ditafsirkannya secara produktif. Sebuah temuan konsepsi kebudayaan yang cukup cemerlang. Dan tidak diragukan lagi, kualitas konsep Ibnu Khaldun ini pulalah yang mungkin mengilhami Zainuddin Sardar dalam merancang kebudayaan Islam di masa depan dengan mempertimbangkan 
aspek historis dimulai dengan masyarakat Islam di Madinah dan faktorfaktor yang mendorong perubahan-perubahan sosial dalam Islam. Konsep itu pulalah yang tampaknya dijadikan standar berpikir Dawood G. RosserOwen dalam mendiskusikan corak masyarakat Islam di masa depan serta dimensi progresif perubahan dalam Islam (Ali, 1985: 334).

Menurut Ibnu Khaldun kompleksitas kebudayaan itu tercipta oleh adanya kemampuan berpikir manusia. Dengan kemampuan itu, manusia melaksanakan gagasannya dan membuat abstraksi-abstraksi. Kemampuan berpikir manusia adalah kedudukan yang berada di luar jangkauan persepsi dan aplikasi pikiran yang digunakan untuk membuat analisis dan membuat sintesa (Ali, 1985: 333).

Menurut Ibnu Khaldun, kemampuan berpikir manusia mempunyai beberapa tingkatan. Tingkatan pertama, adalah pengertian intelektual manusia tentang segala sesuatu yang berada di luar dunia dalam suatu tatanan alamiah atau catatan arbitrasi. Manusia mampu mengatur mereka dengan bantuan kekuatan berpikirnya. Bentuk pemikiran semacam ini kebanyakan berupa persepsi-persepsi. Inilah akal pembeda (al aql at tamyizi) yang membantu manusia memperoleh segala sesuatu yang bermanfaat bagi dirinya, memperoleh penghidupan dan menolak segala yang sia-sia bagi dirinya.

Tingkatan kedua, ialah pikiran yang melengkapi manusia dengan ide-ide dan perilaku yang dibutuhkan dalam pergaulan dengan orang-orang bawahannya dan mengatur mereka. Pemikiran semacam ini kebanyakan berupa apersepsi-apersepsi yang dicapai satu demi satu melalui pengalaman sehingga benar-benar dirasakan manfaatnya. Inilah yang disebut akal eksperimental (al aql at tajribi).

Tingkatan ketiga, adalah kemampuan berpikir yang memberikan manusia pengetahuan (ilmi) atau pengetahuan hipotesis (hypothetical knowledge) mengenai suatu objek yang berada di luar jangkauan sense of perception tanpa praktek kegiatan. Inilah yang disebut Ibnu Khaldun dengan speculative intellect (al aql al nazari). Ia merupakan persepsi dan apersepsi, tasawwur (konsep) dan tasdiq (pembenaran) yang tersusun dalam tatanan 
yang khusus sesuai dengan kondisi-kondisi khusus sehingga membentuk pengetahuan lain dari jenisnya yang sama baik persepsi atau aperseptif. Kemudian semua itu bergabung dengan kemampuan akal yang lain, lalu membentuk pengetahuan yang lain lagi (Ali, 1985: 334).

Dengan kekuatan berpikir inilah kemudian manusia merefleksikan dirinya dalam bentuk kegiatan-kegiatan kehidupan. Refleksi dan kegiatan manusia membentuk kebudayaan. Dengan demikian, bagi Ibnu Khaldun manusia adalah subjek kebudayaan. Perubahan-perubahan dan perkembangan ide, kegiatan dan kebutuhan manusia yang menyebabkan pula terjadinya perubahan daya tanggap manusia terhadap tantangan-tantangan baru akan menyebabkan pula perubahan kebudayaan. Dengan proses yang demikian, manusia mencapai kesempurnaannya dalam realitasnya dan menjadi intelek murni serta memiliki jiwa persepsitif. Inilah makna realitas manusia atau al Haqiqah al Insaniyyah (Ali, 1985: 521-523).

\section{Perenungan Kebudayaan Indonesia Kini dan Esok}

Dalam tafsiran kebudayaan mestinya dapat terjadi saling serapmenyerap dengan indah, yang berguna untuk keberlangsungan keragaman dalam masuknya peradaban-peradaban sepanjang sejarah kebudayaan Indonesia, yang dalam istilah Denys Lombard disebut sebagai Osmosis. Osmosis adalah kelenturan proses menyerap yang terbaik dari lapis budaya etnik lokalitas, ketika bertemu lapis Hinduisme, misalnya, membuahkan cara hidup bersama mengolah tanah dan laut serta organisasi tata hirarki Dewa raja dan pandhita rakyat yang sering menasehati, begitu pula lapis Budhisme, Islam, Cina dan seterusnya (Sutrisno, 2004: 134).

Inti dari proses kebudayaan adalah humanisasi, yakni kerja-kerja peradaban yang semakin mencipta hidup bersama semakin manusiawi, semakin mensejahterakan satu sama lain. Humanisasi dari apa ke mana? Humanisasi dari saling memakan antar sesama bak serigala buas (homo homini lupus), dan ini yang pernah dipraktekkan di era kolonialisme atau bahkan hingga negeri ini merdeka, menuju humanisasi yang memperlakukan manusiawi pada sesama untuk bisa hidup berdampingan 
(homo homini socius) dan beradab (Sutrisno, 2004: 134).

Perumusan strategi kebudayaan dalam konteks Indonesia harus dibuat dengan persepsi budaya yang komprehensif, yang mempunyai cakupan luas terhadap perikehidupan masyarakat Indonesia. Persepsi budaya tidak hanya mengarah pada kesenian belaka, sebab strategi budaya bukan strategi kesenian. Namun cakupan dalam strategi yang berdasar budaya ini mengubah cara hidup, persepsi dan tingkah laku warisan masa lalu. Secara lebih khusus, perubahan tersebut menyangkut semua faktor budaya, yakni: anthropos, oikos, tekne, dan ethnos. Anthropos, berarti manusia menjadi faktor penting dalam membangun bangsa ini, terutama dari sisi kualitas sumber dayanya. Oikos, di mana lingkungan bukan hanya menjadi sarana, akan tetapi merupakan lebenswelt, yakni medan yang memungkinkannya berjuang untuk hidup. Tekne, yakni menjadikan teknologi sebagai perpanjangan tangan dalam meringankan tugas, tekne yang berbasis kemanusiaan dan lingkungan, bukan justru teknik yang membelenggu dan menghancurkan. Sementara ethnos, lebih mengarahkan hidup komunal (Poespowardojo, 1986: 184-186).

Strategi kebudayaan lain juga harus diarahkan untuk mengarah ke masa depan. Warisan budaya harus dihargai, kebudayaan merupakan keseluruhan hasil karya manusia. Suatu kekuatan raksasa yang memandang semua manusia baik secara sosial maupun individual dalam kebudayaan universal manusia. Kata warisan sosial dan tradisi lebih menekankan bagaimana kebudayaan itu dicapai dibandingkan bagian-bagian atau unsurunsurnya. Agar warisan tersebut bermakna diperlukan tafsir ulang yang kreatif dan produktif, seperti dalam bahasa Gadamer, interpretasi bukan hanya mengarah pada teks, ataupun hanya pada konteks teks tersebut dibuat, akan tetapi diperlukan kontekstualisasi yang bersifat produktif, bukan hanya reproduktif (Indarjo, 1994: 8).

Kebudayaan adalah proses belajar yang besar, baik dalam bidang kesenian misalnya, manusia terus menerus mencari bentuk-bentuk atau ekspresi-ekspresi baru, begitu juga dalam bidang teknik ataupun dalam menghadapi alam dan lingkungannya. Proses belajar dalam bidang kebudayaan menghasilkan bentukbentuk baru dan menimbun (akumulasi) pengetahuan dan kepandaian. Ini 
tidak berarti bahwa melalui proses belajar tersebut selalu dihasilkan buah-buah yang positif. Lewat trial dan error (meminjam istilah Popper), kita menjadi lebih bijaksana, kekeliruan dan kesalahan ada manfaatnya. Namun, bisa juga terjadi lewat kesalahan dan kekeliruan manusia menjadi semakin tidak mengerti. Kebudayaan sebagai proses belajar juga tidak akan menjamin kemajuan dan perbaikan sejati apabila tidak memperhatikan "kreterium" dan "evaluasi" secara terus-menerus agar sasaran yang dicapainya sesuai dengan tujuan kemanusiaan.

Merubah rencana kebudayaan berarti manusia memberi sebuah arti dan makna baru kepada segala hal. Seorang budak "menjadi seorang "merdeka", "mata" diganti "mata", "tangan" diganti "tangan", dan seterusnya. Akan tetapi pergantian ini tidak berarti harus menyingkirkan unsur lama, atau bahkan menghilangkan kebutuhan pokok manusia. Dalam diri manusia terdapat dayadaya psikis yang tidak dapat dirubah, dan digantikan begitu saja, meskipun juga harus dipahami bahwa setiap lingkungan kebudayaan terdapat faktor-faktor material ekonomi yang juga tidak dapat diabaikan.

Kebudayaan merupakan semua hal yang mengenai manusia lebih dari biologik/organik saja, akan tetapi kebudayaan pertama-tama mencakup hal badaniyyah dan rohaniyyah kepribadian manusia yang lebih bersama dalam masyarakat. Gejala-gejala kebudayaan itu tidak dapat hanya dimengerti dengan ilmu jiwa biologi saja. Ilmu ini tidak mampu menerangkan bagaimana terjadinya pajak/hukum tata waris, atau sopan-santun, atau doa keagamaan. Mengapa hal ini terus berlangsung hidup dalam masyarakat.

Rumitnya pencarian diri kultural manusia secara kodrati harus dilakukan dengan merefleksikan berbagai tinjauan dan metode yang digunakan oleh para pemikir untuk menelaah sifat kodrati manusia. Pemahaman tentang manusia dan kebudayaan yang diberikan oleh berbagai disiplin keilmuan, seperti sosiologi, biologi, antropologi dan studi-studi budaya lainnya ternyata berhenti pada level empiris. Manusia dipahami dalam dunia ambang, tanpa berusaha melewatinya. Penggunaan metode filsafat tidak berarti lalu menggugurkan berbagai metode terdahulu, melainkan justru melengkapinya atau secara epistemologis bersifat integratif-komplementer. Misalnya saja, filsafat merefleksikan mengenai bentukbentuk simbolis, mulai dari pra-anggapan bahwa andai terdapat definisi tentang 
kodrat atau "hakekat" manusia, maka definisi tersebut hanya dapat dimengerti bersifat fungsional, bukan substansial. Kita tidak dapat mendefinisikan manusia berdasarkan prinsip inheren yang menentukan hakekat metafisiknya, kita pun tidak dapat mendefinisikan manusia berdasar kemampuan atau insting bawaan, meskipun hal tersebut dapat diuji secara empiris.

Akhirnya, dalam strategi tersebut terkandung adanya kondisi dinamis yang mandiri. Berbuat secara mandiri, tidak tergantung ataupun menyandarkan diri pada kebaikan bangsa lain. Masyarakat juga harus mempunyai kemampuan akulturatif, yakni terbuka terhadap unsur-unsur luar, menerima secara selektif dan yang terpenting adalah mampu mengintegrasikannya ke dalam kebudayaan nasional untuk memperkuat identitas kebangsaan, seperti yang telah terbukti dalam sejarah era kultural sebelum masa kolonial.

Sebagai catatan penting bahwa relasi budaya Indonesia dengan unsurunsur asing mengalami tegangan sebagai berikut: bahwa Budaya Indonesia tidak pernah sepenuhnya anti terhadap budaya luar dan dalam, antara "ego" dan "the other". Dominasi kultural tidak akan bisa sungguh-sungguh mendiktekan "the dominated" untuk mengkonstruksi pandangan-pandangan, kebiasaan-kebiasaan dan nilai-nilai yang merupakan tiruan atau mimikri "terjajah dari "penjajah".

Seiring dengan perkembangan pesat dunia modern, rumitnya jejaring kebudayaan Indonesia untuk dipahami. Maka pelacakan identitas Indonesia dengan kembali ke masa lalu, yakni dengan mencari Indonesia murni yang cenderung ke arah puritan dan bahkan puritanisme adalah hal yang kurang bijak, namun mengikuti gerak globalisasi juga harus diperhatikan dengan seksama. Idealnya, pencarian diri kultural Indonesia adalah dengan membiarkannya selalu berada dalam proses persilangan akibat dari perjumpaan dengan budaya-budaya lain.

Agar perumusan identitas itu terus berjalan dengan baik seperti aliran sungai abadi, maka cara yang terbaik adalah membiarkan wacana kebudayaan di Indonesia tetap hidup. Dengan demikian, identitas Indonesia akan selalu berada dalam ruang tarik ulur yang bergerak, yakni ruang ketiga, ruang ambang. Untuk menciptakan ruang wacana yang melibatkan sebanyak etnis di Indonesia inilah kiranya perlu terus dikembangkan. Dengan demikian, kebangsaan memang bukanlah suatu entitas yang jadi dan untuk proses redefinisi menjadi 
Indonesia perlu diciptakan keindonesiaan yang interaktif antar etnis, gerakan yang bergerak terus-menerus, dalam kondisi Indonesia yang demoktratis.

Dengan demikian, refleksi filosofis atas manusia dan kebudayaan tidak hanya berhenti atau puas dengan menganalisis bentuk-bentuk kebudayaan tertentu. Filsafat mencari pandangan universal yang merupakan sintesis dari tinjauan atas semua bentuk partikular, tanpa harus berambisi untuk mencapai pengetahuan yang total di bawah satu payung paradigma. Filsafat kontemporer ini juga harus mampu mendiskursuskan berbagai subjek kebudayaan untuk direfleksikan secara mendalam. Filsafat kebudayaan mengusahakan penekanan lebih jauh lagi struktur yang mendasari keanekaragaman dan kemajemukan citra mitos, religi, bahasa, dan karya seperti yang dinarasikan oleh ilmu-ilmu budaya.

\section{Simpulan}

Konsep kebudayaan Ibnu Khaldun tidaklah berhenti sampai di sana. 'Umran (kebudayaan) sebagai suatu kreasi manusia mempunyai sebuah "dimensi historis". Baginya, kebudayaan tidak hanya suatu warisan dari kebudayaan terdahulu, melainkan juga 'umran in becoming (kebudayaan di masa depan). Sebuah temuan konsepsi kebudayaan dalam merancang kebudayaan Islam di masa depan dengan mempertimbangkan aspek historis dan faktor-faktor yang mendorong perubahan-perubahan sosial dalam Islam. Konsep ini tampak dapat dijadikan acuan dalam mendiskusikan corak masyarakat Islam di masa depan serta dimensi progresif perubahan dalam Islam. Penelitian Ibnu Khaldun mengenai karakter kebudayaan desa dan kota yang ditentukan oleh metode dan pendekatan empiris-positif yang digunakannya. Prinsip infisal (discontinu) menjadi corak khas masyarakat, sebab prinsip keterpisahan/ketidaksinambungan ini memandang bahwa alam seisinya ini masing-masing berdiri sendiri dan tidak berkaitan satu dengan yang lainnya. Prinsip diskontinuitas ini didasarkan Ibnu Khaldun pada pengaruh kondisi geografis alam sekitar, baik berkenaan dengan padang pasir, misalnya, terdapat unit-unit yang independen terpisah antara satu dengan lainnya. Di samping itu, beberapa karakter sosiologis dan kultural juga sangat mewarnai pola kehidupan masyarakat desa dan kota. 


\section{Daftar Pustaka}

Ali, Fachry. 1985. Realitas Manusia: Pandangan Sosiologis Ibnu Khaldun. Jakarta: Grafitti Press.

Indarjo, Mispan. 1994. Gambaran Pengalaman Hermeneutik Hans-Georg Gadamer. Driyarkara. No. 3/Tahun xx.

Jarvie, I. C. 1983. Technology and the Structure of Knowledge. New York: The Free Press.

Lubis, Muchtar. 1981. Penerusan Kebudayaan Kita Terputus. Prisma, 11 Novermber.

Poespowardojo, Soerjanto. 1986. Refleksi Budaya Mengenai Pembangunan Nasional. Jakarta: Tidak diterbitkan.

Sastrapratedja, M. 1977. Pokok-pokok Pandangan Ibnu Khaldun Mengenai Kekuasaan. Driyarkarya, seri 4. Yogyakarta: Kanisius.

Sutrisno, Muji dan Hendar Putranto. 2004. Hermeneutika Pasca-kolonial: Soal Identitas. Yogyakarta: Kanisius. 